\title{
Fe-Mn nodules associated with hydrocarbon seeps: A new discovery in the Gulf of Cadiz (eastern central Atlantic)
}

\author{
1 Marine Geology Dv., Geological Survey of Spain (IGME). C/ Ríos Rosas 23, 28003 Madrid, Spain. E-mail:fj.gonzalez@igme.es \\ 2 Departamento de Cristalografía y Mineralogía, Universidad Complutense de Madrid (UCM). C/ José Antonio Novais 2, Ciudad Universitaria, \\ 28040 Madrid, Spain. \\ 3 Centro de Astrobiología (CSIC/INTA). 29006 Torrejón de Ardoz (Madrid), Spain. \\ 4 Laboratorio de Estratigrafía Biomolecular (ETSIM/UPM). C/ Ríos Rosas 21, 28003 Madrid, Spain. \\ 5 Centro Oceanográfico de Málaga, Instituto Español de Oceanografía (IEO). Apdo. 285, 29640 Fuengirola (Málaga), Spain.
}

The Gulf of Cadiz is situated geologically at the Gibraltar Arc, the westernmost arc of the AlpineHimalayan orogenic belt. Based on extensive previous studies that include swath bathymetry, multi-channel and very high-resolution seismic reflection, gravimetry, magnetism, heat flow probes, and underwater photography surveys, more than 500 polymetallic nodules were collected at water depths ranging from 850 to $1000 \mathrm{~m}$, associated with hydrocarbon-derived carbonate chimneys, slabs, and crusts. Nodules show a wide range of sizes, densities, weights and morphologies. Nodules are composed of multiple millimetre-thick layers of $\mathrm{Fe}$ and Mn oxyhydroxides surrounding a nucleus composed of Early-Middle Miocene plastic marls, which were expulsed from underlying units by fluid venting. Nodules show a high mean abundance of $\mathrm{Fe}$ (39.03\%), moderate $\mathrm{Mn}(5.84 \%)$, and low contents of trace metals and REEs compared to the average content of deep-sea polymetallic nodules. They display fast growth rates (av. 2,500 mm Myr-1) which are probably the main cause for the low contents of transition metals. The oxide layers contain both bacterial-derived hydrocarbons and aromatic hydrocarbons such as phenanthrene, characteristic of mature hydrocarbons. We propose both diagenetic and hydrogenous processes for nodule, beneath and on the seabed, as consequence of alternating episodes of burial and exhumation. Diagenetic processes beneath the seabed are fuelled by deep-seated hydrocarbon seeps probably through microbial-mediated anaerobic oxidation of hydrocarbons. On the other hand, hydrogenous nodule growth on the seafloor is controlled by mineral precipitation from the Mediterranean Outflow Waters.

\section{Introduction}

Polymetallic nodules were first discovered in 1868 in the Kara Sea, Russia (Murray and Renard, 1891). With the advance of underwater exploration techniques during the 1960s and 1970s, seabed polymetallic nodules were considered a potential economic resource of great interest (Rona, 2002). Deposits of Fe-Mn nodules are distributed in all the oceans of the world, although there are some areas where they are especially abundant or rich in elements of economic

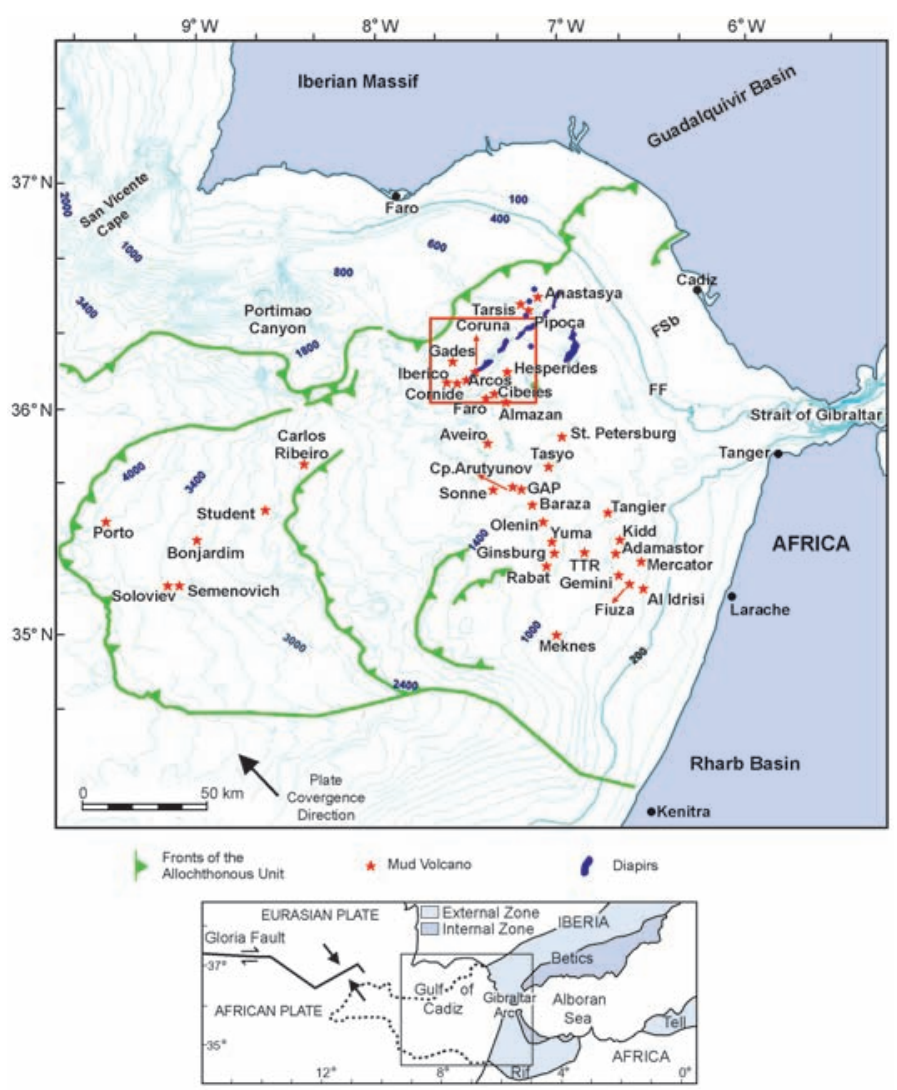

Figure 1 Geological setting and simplified bathymetry of the Gulf of Cadiz. The rectangle marks the location of the nodule field in the Guadalquivir Diapiric Ridge area. Bathymetry in meters. Partially modified from León et al. (2006). 
interest, such as the Clarion-Cliperton Zone in the northeast Pacific Ocean, the Central East Indian Basin in the Indian Ocean and the Peru Basin in the south-eastern Pacific Ocean (e.g., Cronan, 1977; Rona, 2003). During the last four decades, the prospecting and research for polymetallic nodules and crusts has been very active (e.g., Glasby, 1977; Nicholson et al., 1997; Dekov and Savelli, 2004; Verlaan et al., 2005). In this way, the International Seabed Authority (ISA) approved in 2000 regulations and environmental guidelines for exploration for polymetallic nodules in "The Area", seabed beyond national jurisdiction (ISA, 1999; ISA, 2000).

The importance of seabed resources in the Gulf of Cadiz (Figure 1) was unknown until the advent of such technologies as multibeam bathymetry echosounders and long-range side-scan sonars for deep marine exploration. Several cruises were carried out aboard the research vessels "Prof. Logachev", "Hespérides", and "Cornide de Saavedra" from 1999 to 2005 in the Gulf of Cadiz. Cooperation between the IOC-UNESCO "Training Through Research" TTR cruises and the "TASYO" project led to the discovery of large fields of fluid venting structures in the Gulf of Cadiz such as mud volcanoes bearing gas hydrates (Ivanov et al., 2000; Gardner, 2001; Somoza et al., 2002), ankerite and dolomite chimneys, nodules, crusts, and slabs (Somoza et al., 2003; Díaz-del-Río et al., 2003; Magalhães et al., 2005; León et al., 2006), and more recently, Fe-Mn nodules (González, 2004) associated with these structures in this tectonically active area.

Here we present underwater images and detailed physical, mineralogical, and geochemical description of the Fe-Mn nodules that were recently discovered along the continental margin of the Gulf of Cadiz. The nodules are associated with hydrocarbon-related seeps. In addition, we present a comparative analysis with other deepseabed polymetallic nodules, and shallow-water and continental margin nodules from other ocean basins and tectonic settings of the world.

\section{Geological setting}

The Gulf of Cadiz is located at the westward front of the Betic-Rifian Arc, in the easternmost sector of the Azores-Gibraltar segment of the Africa/Eurasia collisional plate boundary (Dewey et al., 1989) (Figure 1). It has a complex geological history and has undergone several episodes of rifting, compression, and strike-slip motion since the Triassic (Maldonado et al., 1999). In late Tortonian times (7,1-11,2 Ma), a large sedimentary body was emplaced in the Gulf of Cadiz, caused by westward migration of the Alboran domain associated with the formation of the Betic-Rifian Arc (Bonnin et al., 1975; Auzende et al., 1981; Lonergan and White, 1997; Maldonado et al., 1999). During the final stages of accretion of the Betic-Rifian Arc and the emplacement of thrust units, gravitational sliding of mobile shale and salt stocks formed a giant complex of mass-wasting deposits, generally known as the "Gibraltar Olistostrome", that reached as far west as the Horseshoe and Seine abyssal plains. This feature appears as a chaotic, highly diffractive body, with highamplitude reflections on seismic sections (Riaza and Martínez del Olmo, 1996) and it consists of a mixture of Triassic, Cretaceous, Paleogene, and Neogene sedimentary units, overlying Palaeozoic basement (Maldonado et al., 1999). It involves a huge volume of mud and salt diapirism of Triassic salt units and undercompacted Early-Middle Miocene plastic marls (Maestro et al., 2003). The origin of this chaotic body is highly controversial. It has been interpreted as a complex of olistostromes and debris flows, originated by gravitational sliding and tectonic thrusted units - tectonic mélanges (Torelli et al., 1997; Maldonado et al., 1999; Medialdea et al., 2004). Alternatively, it was also interpreted as an accretionary complex related to migration of the Alboran terrain as a consequence of a once active subduction zone (Royden, 1993). Recently, Gutscher et al. (2002) proposed that this subduction is still active beneath Gibraltar.
Throughout this area, extensive hydrocarbon-rich fluid venting and mud diapirism are observed, which includes numerous mud volcanoes, methane-related authigenic carbonates (crusts, chimneys and carbonate mounds) and pockmarks (Baraza and Ercilla, 1996; Gardner, 2001; Ivanov et al., 2000; Diaz-del-Rio et al., 2003; Pinheiro et al., 2003; Somoza et al., 2003). These are related to the lateral compression from Africa-Eurasia convergence, which promoted fluid migration to the surface. Several NE-SW oriented diapiric mud ridges have been found in the NE sector of the Gulf of Cadiz, which are characterised by abundant carbonate chimneys and crusts on top of these ridges (Diaz del Rio et al., 2001; Somoza et al., 2003; Fernández Puga, 2004). Focal mechanism solutions show that the stress regime along the Africa-Eurasian plate boundary in this area is a combination of dextral strike-slip and a NW-directed compression near Gorringe Bank and the Gulf of Cadiz (Borges et al., 2001). Presently, the direction of maximum horizontal compressive stress along this segment of the plate boundary is estimated to be approximately WNW-ESE in the Gulf of Cadiz, leading to a general transpressive regime (Cavazza et al., 2004).

We must emphasise the role of the Gulf of Cadiz for the outflow of the Mediterranean waters from the Strait of Gibraltar towards the Atlantic Ocean, causing specific biotic and temperature conditions over the seabed. The Mediterranean Outflow Water (MOW) crosses the Strait of Gibraltar and is channelled through existing submarine channels from 600 to $1200 \mathrm{~m}$ water depth along the continental slope of the Gulf of Cadiz (Hernández Molina et al., 2003).

\section{Sampling and analytical methods}

Data presented here were acquired during the oceanographic cruises Tasyo/2000 and Anastasya/2000/2001 aboard the research vessels "Hespérides" and "Cornide de Saavedra". The study area $(8,500$ $\mathrm{km}^{2}$ ) was extensively surveyed with swath bathymetry, multi-channel and very high-resolution seismic reflection, gravimetry, magnetism, heat flow probes, underwater cameras, dredging, and gravity coring. Navigation was by differential Global Positioning System (DGPS) for which the average navigational accuracy is estimated to be better than $5 \mathrm{~m}$. Multibeam echo-sounder EM12S-120 operated at a main frequency of $13 \mathrm{kHz}$, with 81 beams, which allowed a maximum coverage angle of $120^{\circ}$ (about three times the water depth). This system, triggered with a range of pulse lengths from $2-10 \mathrm{~ms}$, has a vertical resolution of $0.6 \mathrm{~m}$. A bathymetric map, contoured at an interval of $10 \mathrm{~m}$ and a seafloor backscatter image was generated (León et al., 2001). A dense network of parametric echo-sounder TOPAS (Topographic Parametric Sound) and Sparker seismic data were collected. Sparker data $(50 \mathrm{~Hz}-4 \mathrm{kHz})$ were collected during cruises Anastasya-99 and Anastasya-00 with an energy source ranging between 3500 and 7000 Joules and a recording length of $2 \mathrm{~s}$ TWT. Submarine photographs were taken with a Benthos-372 underwater deep-sea camera during the cruise Anastasya-01 after detailed bathymetric surveys. The seabed images were very useful in order to establish the relationships between seabed structures and to identify targets for dredging and coring. Twenty dredges (benthic type) and 22 gravity cores were taking along a sector determined from bathymetric, seabed reflectivity, and magnetism maps.

Analytical work was done at the Laboratories of the Geological Survey of Spain (IGME), the "Centro de Astrobiología" (CAB), the "Laboratorio de Estratigrafía Biomolecular" at the Polytechnic University of Madrid (UPM) and the "Centro de Microscopía Electrónica Luis Bru" at the Complutense University of Madrid (UCM). We recovered from the seabed $561 \mathrm{Fe}-\mathrm{Mn}$ nodules with a total weight of 36,6 kg. Macroscopic descriptions (morphology, colour, surface texture, sphericity, weight and size) were made for each of the 561 samples and calculations of density and porosity were made for 42 samples. Apparent wet bulk density and open porosity were determined by water absorption in void according to the UNE-EN 1936:1999 normative. Real dry bulk density was calculated by the helium pycnometer method with an Accupyc 1330 pycnometer. 
Optical and electron microscopy (EPMA), scanning electron microscopic analysis (SEM-EDS), X-ray diffraction (XRD), X-ray fluorescence (XRF), atomic absorption spectroscopy (AAS), inductively coupled plasma-atomic emission spectroscopy (ICP-AES), and ICPmass spectroscopy (ICP-MS) were made for 25 selected samples among the various morphological types. TOC was made for 14 bulk nodules by subtracting the TIC obtained by calcination at $550^{\circ} \mathrm{C}$, from the TC values and measured in ELTRA CS-800 equipment. Biomarkers were analyzed by combined gas chromatography-mass spectrometry (GC-MS). Component identification was based on comparison of the mass spectra and the GC retention times with published data and reference compounds.

\section{Nodule fields}

Nodule fields extend along the middle continental slope at an average depth of $900 \mathrm{~m}$. The most prominent physiographic features of this sector are: A) a NE-SW diapiric ridge with a vertical relief of 300 m named Guadalquivir Diapiric Ridge (Somoza et al., 2003) and, b) the Cadiz Channel through which the Mediterranean Outflow Water (MOW) undercurrent circulates. Several individual mounds were identified along the Guadalquivir Diapiric Ridge. Dredge hauls from the top of these mounds yielded large amounts of carbonate crusts and chimneys and mud-breccia flow deposits composed mainly by ejected materials, mostly Miocene marls and muds. Indications of gas saturation include degassing structures, the presence of hydrogen sulphide $\left(\mathrm{H}_{2} \mathrm{~S}\right)$, and chemosynthetic fauna (Pogonophora sp. tube worms, Calyptogena sp. and Acharax sp.). The fields of $\mathrm{Fe}-\mathrm{Mn}$ nodules occur at the base of the mounds, where the influence of the MOW is strong and where rippled seabed and carbonate crusts and chimneys also occur (Figure 2). The underwater images show a variable density of nodules overlying the seafloor, from $3 \%$ to $75 \%$, fundamentally together with carbonate chimneys

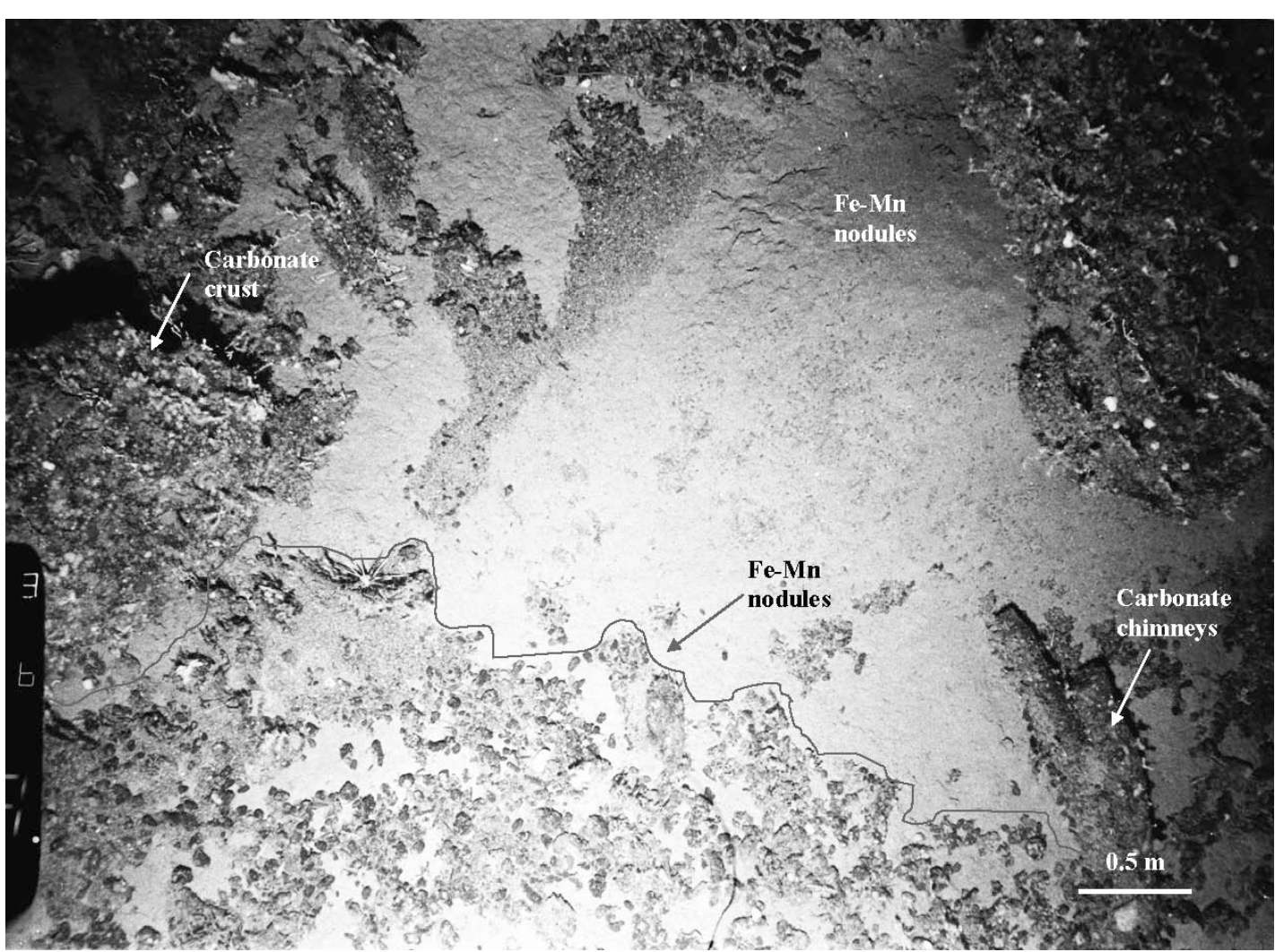

Figure 2 Underwater image showing Fe-Mn nodules lying on the seabed. They were photographed in the area surrounding the Guadalquivir Diapiric Ridge (with a rectangle in Figure 1). Nodules show a patchy distribution and are close to hydrocarbon-derived carbonate slabs covered by deep corals, sponges, and echinoids. Two carbonate chimneys are also observed lying on the seabed. and crusts. Commonly the nodules are characterised by tabularirregular morphologies, absence of encrusting benthic organisms, and black colour, appearing in a patchy distribution on the seabed. The surface sediments in the nodules fields are highly oxidized and brown in colour, but the subsurface sediments, only a few centimetres below, are olive-grey muds and silts containing $\mathrm{H}_{2} \mathrm{~S}$ and pyrite.

\section{Macroscopical, mineralogical, and geochemical characterisation}

The nodules of the Gulf of Cadiz are characteristic for displaying different morphological types: tabular, irregular, discoidal, subspherical, ellipsoidal, and cylindrical, but the most abundant is the tabular morphology (Figure 3B). The surface texture is smooth to rough, and botryoidal. Colour varies between orange and black and reflects the fundamental chemical composition of the samples: iron oxyhydroxides. The maximum diameter varies between 1.6 and 20.4 $\mathrm{cm}$, weight is between 1.37 and $1,818.8 \mathrm{~g}$, porosity between 23.9 and $44.3 \%$ in volume, and dry bulk density between 3.3 and $3.5 \mathrm{~g} / \mathrm{cm} 3$ (Table 1). The internal structure of the nodules is defined by the nucleus and the layers that surround it. With regard to the nucleus, samples with one or more nuclei and samples of aggregated nodules exist (Figure 3D). The nucleus usually has a tabular form, is of centimetre size, and composed of marl (Miocene marl clasts). The oxides form multiple millimetre-sized layers, and in some samples are distributed in continuous concentric laminae around the nucleus (especially in small nodules), whereas in other nodules (big samples and composite nodules) occurs a complex arrangement of laminae. Some nodules, especially those of bigger size, show the occurrence of detrital layers and burrowing inside the detrital layers. Detrital layers are characterised by the abundance of angular grains (mud and silt)

forming continuous layers with thickness ranging from 1 to several millimetres. These detrital layers seem to be overprinted by the concentric oxide layers. Most of the nodules studied show an external alteration front comprising about 2 to $5 \mathrm{~mm}$ of the outer layers, being characterized by colours ranging from orange to yellow and by a high porosity (Figure $3 \mathrm{~B}$ ).

The fundamental mineralogical components of oxide layers of the nodules are: goethite a $\mathrm{Fe} \mathrm{OOH}$, lepidocrocite $\mathrm{g} \mathrm{Fe} \mathrm{OOH}$, birnessite $(\mathrm{Na}, \mathrm{Ca}, \mathrm{K}) \mathrm{x}$ $\mathrm{Mn}_{2} \mathrm{O}_{4} * 1.5 \mathrm{H}_{2} \mathrm{O}$, jianshuiite $(\mathrm{Mg}, \mathrm{Mn}) \mathrm{Mn}_{3} \mathrm{O}_{7}$ $* 3 \mathrm{H}_{2} \mathrm{O}, 10 \AA$ manganates, pyrolusite $\mathrm{Mn} \mathrm{O}_{2}$, quartz and phyllosilicates (illite, smectite, kaolinite). Accessory minerals are calcite, dolomite, kutnohorite $\mathrm{Ca}$ $(\mathrm{Mn}, \mathrm{Mg}, \mathrm{Fe})\left(\mathrm{CO}_{3}\right)_{2}$, pyrite, chalcopyrite, potassium feldspar, zircon, rutile and chlorite. Nuclei are essentially composed by siderite, calcite, dolomite, 

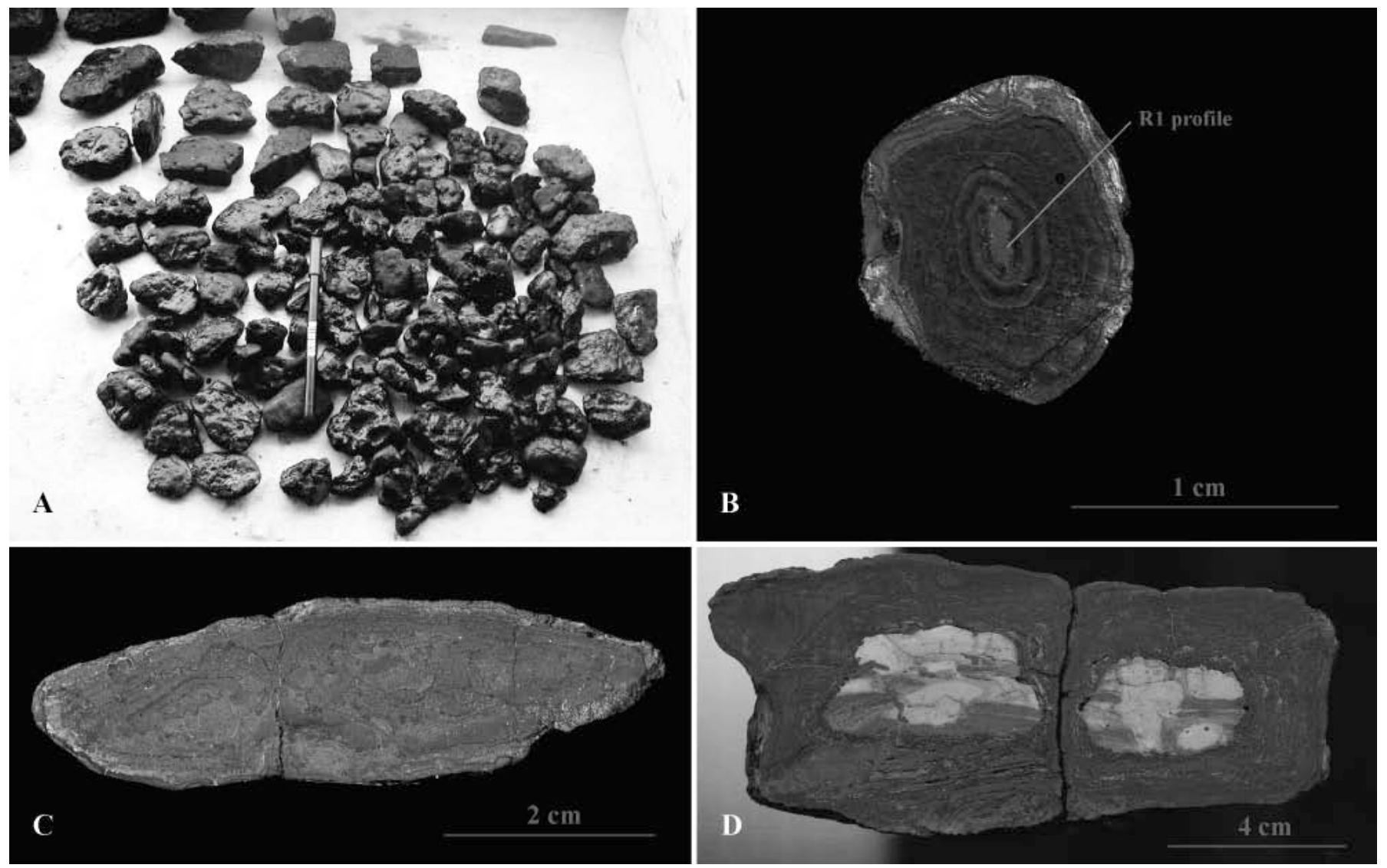

Figure 3 (A) set of dredged nodules from the oceanographic cruise Anastasya-2001 near to the Guadalquivir Diapiric Ridge, (B) cross section of a sub-spherical nodule (sample ANAS01/D19-01) with concentric millimetric layers and an alteration front affecting the outer layers, $(C)$ discoidal nodule without distinguishable nucleus, $(D)$ tabular composite nodule formed by accretion of two nodules. Nuclei are Miocene marl clasts.

quartz, and phyllosilicates strongly impregnated of Fe-Mn oxides from the oxide layers.

The detritic minerals (rock fragments within the oxide layers) are quartz, feldspars, calcite, dolomite, zircon, rutile, and phyllosilicates (illite, smectite, kaolinite, and chlorite). Subangular to angular detrital grains of quartz, calcite, and dolomite are thought to be fluid and mud ejecta. The other detrital components, with more rounded appearance, may have the same source or come from hemipelagic or contourite sediments. The authigenic minerals are goethite, lepidocrocite, pyrite, chalcopyrite, birnessite, jianshuite, $10 \AA$ manganates, pyrolusite, micritic calcite and kutnohorite. Iron oxides also appear as chemical precipitates, especially in the layers affected by the alteration front. Fe-Mn oxyhydroxides appear as micro-crystalline to amorphous aggregates forming laminar, massive, speckled, and dendritic structures (Figures 4A, 4B). Fracture discontinuities are millimetric to centimetric in length and millimetric in width, frequently filled with detrital sediment, carbonate precipitates, $\mathrm{Fe}-\mathrm{Mn}$ oxides, and occasionally sulphides. These fractures are perpendicu-

Table 1 General physical characteristics of the nodules from the Gulf of Cadiz.

\begin{tabular}{c|c}
\hline Maximum diameter $(\mathrm{cm})$ & $1.6-20.4$ \\
\hline Dry weight in air $(\mathrm{g})$ & $1.37-1,818.8$ \\
\hline Apparent wet bulk density $\left(\mathrm{g} / \mathrm{cm}^{3}\right)$ & $1.8-2.6$ \\
\hline Real dry bulk density $\left(\mathrm{g} / \mathrm{cm}^{3}\right)$ & $3.3-3.5$ \\
\hline Open porosity (Volume $\%)$ & $23.9-44.3$ \\
\hline Colour & Orange-black \\
\hline
\end{tabular}

lar or parallel to Fe-Mn layers, commonly marking accretion limits between single nodules in composite samples (Figure 3D).

Goethite-Mn oxides crystals have idiomorphic to sub-idiomorphic rhombic sections being normally surrounded by a mixture of phyllosilicates and Mn-oxides, and in places by carbonates filling micro-fractures (Figure 4C). These rhombic crystals range from 2 to $10 \mu \mathrm{m}$ showing a characteristic internal zonation composed by fibrous-texture Mn-oxides in the inner part and Fe-oxides in the outer edge. Goethite normally occurs in the oxide layers as rhombic crystals, and less often, forming framboidal and sub-idiomorphic cubic/octahedral aggregates derived from partial or total replacement of pyrite. Goethite also replaces carbonates of bioclastic shells. Both rhombic crystals and framboidal aggregates appear to be in textural equilibrium (Figure 4D). Rhombic textures of Fe-Mn oxides are observed within the outer layers affected by the alteration front, although colloform goethite filling the pores has been also frequently observed. Generally, pyrite occurs as framboidal aggregates which have been partial or totally pseudomorphed by goethite. These pyrite aggregates show positive to highly negative $\delta^{34} S_{C D T}$ isotopic values ranging between +13 and $-41 \%$. SEM observations revealed abundant microbe-like structures, composed of goethite-Mn oxides with a significant quantity of C (up to $24 \%$ ), filamentous or bulbous morphology and a length ranging from 1 to $3 \mu \mathrm{m}$.

Nodules from the Gulf of Cadiz are characteristically rich in $\mathrm{Fe}$ (up to $45 \%$ ) and moderately enriched in Mn (up to $9 \%$ ). Iron is the most abundant element in the nodules followed by $\mathrm{Mn}, \mathrm{Si}$, and $\mathrm{Ca}$. The contents of $\mathrm{V}, \mathrm{As}, \mathrm{Ca}, \mathrm{Mg}, \mathrm{Ni}, \mathrm{Co}$, and $\mathrm{Mo}$ are enriched compared to the mean Earth's crust (Evans, 1980) (Table 2). Nodules display no to a slightly negative $\mathrm{Ce}$ anomalies ranging between -0.11 and +0.04 .

EPMA profiles with analysis points every $50 \mu \mathrm{m}(\mathrm{Fe}, \mathrm{Mn}, \mathrm{Co}$, $\mathrm{Ni}, \mathrm{Cu}, \mathrm{Zn}, \mathrm{Si}, \mathrm{Al}, \mathrm{V}, \mathrm{P}, \mathrm{As}, \mathrm{Ca}$, and $\mathrm{Mg}$ ) have been carried out from 

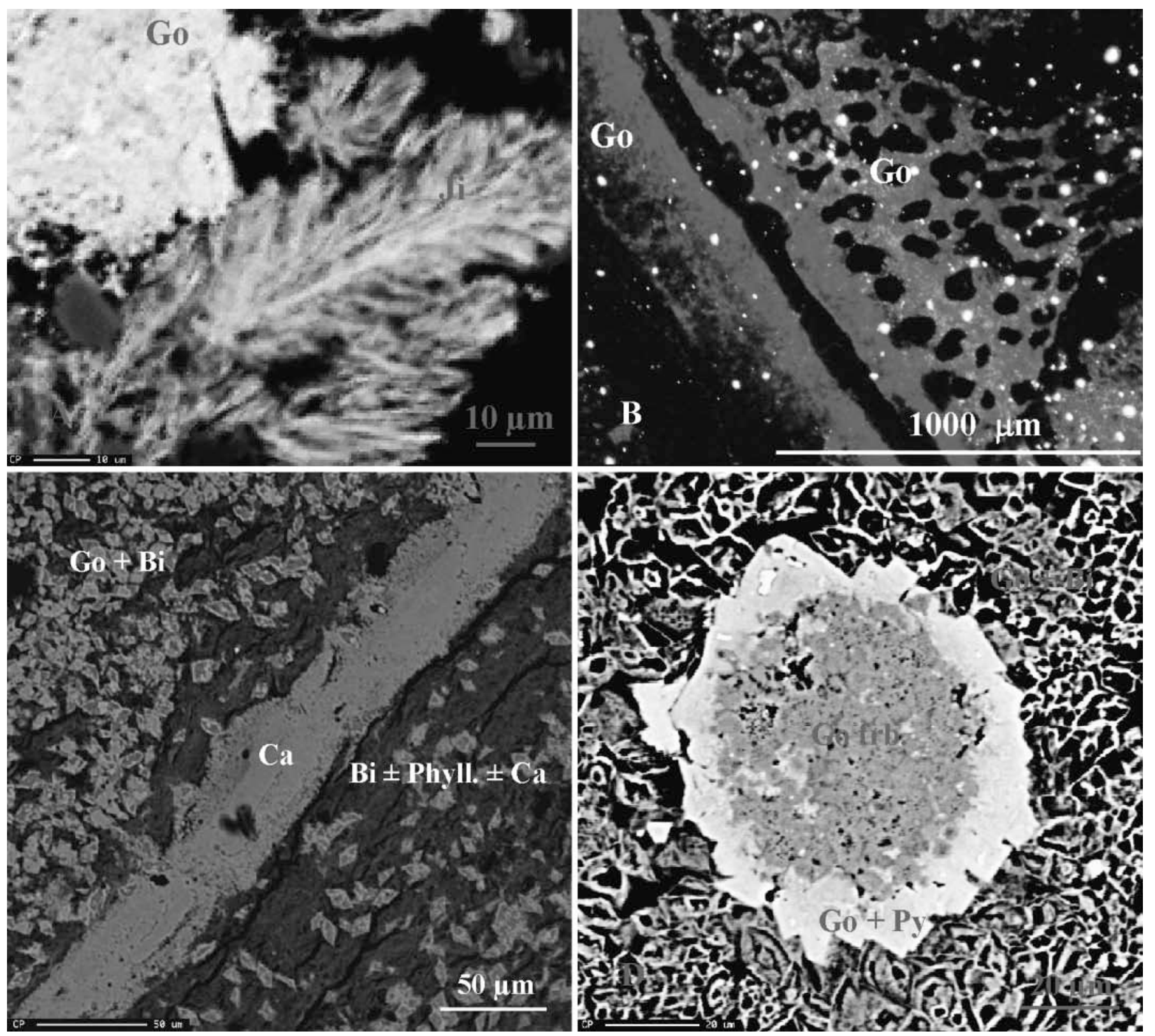

Figure 4 (A) electron microscope (back-scattered electrons) photograph of jianshuite (Ji) with feather structure filling a hollow next to micro-crystalline goethite (Go), (B) optical microscope (transmitted light) photograph in natural light. Two textures most characteristic of the studied nodules are observed: the laminate and the speckled, $(C)$ electron microscope (back-scattered electrons) photograph of an oxide layer showing goethite-birnessite rhombic crystals $(\mathrm{Go}+\mathrm{Bi})$ surrounded by Mn-oxides (Bi) and crosscut by a post-depositional crack filled with carbonates $(\mathrm{Ca}),(\mathrm{D})$ pyrite aggregate formed by framboids (inside) and idiomorphic cubic crystals (outside), partially pseudomorphsed by goethite in textural equilibrium with $\mathrm{Fe}-\mathrm{Mn}$ rhombic crystals $(\mathrm{Go}+\mathrm{Bi})$.

the nucleus to the outer layers of the different types of nodules. As an example, the R1-EPMA profile (see Figure 3B) of sample ANAS01/D19-01 shows that the external layers affected by the alteration front are strongly enriched in $\mathrm{Fe}$ (av. 45\%), $\mathrm{P}$ (av. $0.29 \%$ ), Zn (av. 0.08\%), V, As, and Co (av. 0.06\%) and depleted in $\mathrm{Mn}(\mathrm{av} .1 \%$ ) in relation to the rest of the nodule. Pearson correlation coefficients of this profile show a positive correlation of iron (at 99\% confidence level) with Co $(n=150 ; r=0.80)$, $\mathrm{P}(\mathrm{n}=150 ; \mathrm{r}=0.74)$, and $\mathrm{V}(\mathrm{n}=150 ; \mathrm{r}=0.68)$ and somewhat lower with As $(n=150 ; r=0.43)$. Otherwise, iron has negative correlations with $\mathrm{Ca}(\mathrm{n}=150, \mathrm{r}=-0.59)$ and $\mathrm{Mn}(\mathrm{n}=150, \mathrm{r}=-0.57)$. Mn has a weak correlation with $\mathrm{Mg}(\mathrm{n}=150 ; \mathrm{r}=0.36)$. In bulk samples, $\mathrm{Si}$ and $\mathrm{Al}$ are correlated $(\mathrm{n}=25 ; \mathrm{r}=0.87)$ and both are correlated with $\mathrm{K}(\mathrm{n}=25 ; \mathrm{r}=0.88$ to 0.92$)$, all present in silicates.
The mean value for TOC in 14 bulk samples is $1.12 \%$ with contents ranging between 0.33 and $3.85 \%$. The presence of biomarkers has been detected based on semi-quantitative analyses of powdered samples of oxide layers. Gas chromatograms of the total hydrocarbon fraction show a similar pattern in all the studied samples, comprising a modal n-alkane distribution with a first concentration maximum at $\mathrm{n}-\mathrm{C}_{18}$ and an important presence at $\mathrm{n}-\mathrm{C}_{16}$ and $\mathrm{n}-\mathrm{C}_{20}$. The chromatograms present a convex morphology known as an unresolved complex mixture (UCM), characteristic of samples which underwent an intense degree of marine microbial degradation. Moreover, the carbon preference index (CPI) ranges from 0.66 to 1.15 , which is also characteristic of mature samples. In addition, phenanthrene was detected in all the nodules analysed, which only occurs in petroleum and coals with a high mature degree. Fatty acids are detected in all the nodule samples 
Table 2 Average content of major (wt. \%) and trace elements ( $\mu \mathrm{g} / \mathrm{g}$ ) of the Earth's crust, deep sea nodules and the nodules of the Gulf of Cadiz. (a) Total Earth's Crust from Evans (1980). (b) Global mean from Baturin (1988). (c) This work, bulk chemical composition. - : Without data. <d/l: less than detection limit.

\begin{tabular}{|c|c|c|c|c|c|c|c|}
\hline \multirow{2}{*}{ Element } & \multirow{2}{*}{ Earth's Crust (a) } & \multirow{2}{*}{$\begin{array}{l}\text { Oceanic nodules, } \\
\text { global mean (b) }\end{array}$} & \multicolumn{5}{|c|}{ Nodules from the Gulf of Cadiz (c) } \\
\hline & & & $\mathrm{n}$ & Mean & SD & Min. & Max. \\
\hline $\mathrm{Si}$ & 27.72 & 7.69 & 25 & 3.51 & 0.9 & 1.75 & 5.26 \\
\hline $\mathrm{Al}$ & 8.13 & 2.70 & 25 & 1.39 & 0.3 & 0.92 & 1.98 \\
\hline $\mathrm{Fe}$ & 5.00 & 12.47 & 25 & 39.03 & 3.1 & 33.06 & 45.06 \\
\hline $\mathrm{Ca}$ & 3.63 & 2.23 & 25 & 3.03 & 1.6 & 0.62 & 6.57 \\
\hline $\mathrm{Na}$ & 2.83 & 1.97 & 25 & 0.22 & 0.2 & 0.03 & 0.69 \\
\hline $\mathrm{K}$ & 2.59 & 0.73 & 25 & 0.34 & 0.1 & 0.20 & 0.52 \\
\hline $\mathrm{Mg}$ & 2.09 & 1.57 & 25 & 1.83 & 0.3 & 1.03 & 2.21 \\
\hline $\mathrm{Ti}$ & 0.44 & 0.69 & 25 & 0.10 & 0.0 & 0.06 & 0.14 \\
\hline$P$ & 0.10 & 0.37 & 25 & 0.20 & 0.1 & 0.06 & 0.29 \\
\hline $\mathrm{Ba}$ & 425 & 2,300 & 24 & 347 & 140.2 & 127 & 694 \\
\hline $\mathrm{Mn}$ & 950 & 18.60 & 25 & 5.84 & 1.9 & 3.01 & 9.12 \\
\hline $\mathrm{V}$ & 135 & 520 & 24 & 345 & 105.1 & 163 & 532 \\
\hline $\mathrm{Cr}$ & 100 & 70 & 24 & 32 & 9.8 & 21 & 62 \\
\hline $\mathrm{Ni}$ & 75 & 6,600 & 24 & 107 & 69.0 & 43 & 404 \\
\hline $\mathrm{Zn}$ & 70 & 1,200 & 24 & 66 & 19.6 & 32 & 111 \\
\hline $\mathrm{Ce}$ & 60 & 720 & 24 & 40 & 10.9 & 13 & 56 \\
\hline $\mathrm{Cu}$ & 55 & 4,500 & 24 & 39 & 11.2 & 10 & 62 \\
\hline La & 30 & 210 & 20 & 15 & 5.3 & 6 & 24 \\
\hline Co & 25 & 2,700 & 24 & 89 & 14.2 & 60 & 116 \\
\hline Sc & 22 & 50 & 24 & 18 & 2.9 & 13 & 23 \\
\hline $\mathrm{Nb}$ & 20 & 70 & 24 & 5 & 1.1 & 3 & 7 \\
\hline $\mathrm{Pb}$ & 13 & 930 & 24 & 20 & 24.7 & 6 & 121 \\
\hline $\mathrm{Be}$ & 2.8 & 10 & 0 & - & - & - & - \\
\hline As & 1.8 & 140 & 24 & 161 & 78.3 & 23 & 303 \\
\hline Mo & 1.5 & 380 & 24 & 47 & 8.9 & 30 & 69 \\
\hline$w$ & 1.5 & 100 & 8 & 8 & 4 & 3 & 14 \\
\hline $\mathrm{Cd}$ & 0.2 & 10 & & $<\mathrm{dl}$ & & & $<\mathrm{dl}$ \\
\hline $\mathrm{Sb}$ & 0.2 & 50 & 5 & 4 & 0.5 & 3 & 4 \\
\hline $\mathrm{Ag}$ & 0.07 & 10 & & $<\mathrm{dl}$ & & & $<\mathrm{dl}$ \\
\hline
\end{tabular}

being composed by saturated acids $\left(\mathrm{C}_{14}-\mathrm{C}_{18}\right)$ which indicates a bacterial origin.

\section{Nodule growth rates}

Studies on marine ferromanganese nodules have suggested a relationship between their growth rate and their chemical composition (e.g., Reyss et al. 1982). The suggestion is based on the hypothesis that the metals in nodules have two sources of supply: bottom seawater (hydrogenous) and sediment pore water (diagenetic). Following this assumption, the Co method (cobalt chronometer) is normally used to determinate age in $\mathrm{Fe}-\mathrm{Mn}$ concretions based in the relation between Co content and growth rate. Various authors have established equations, and one of the most accepted is the equation proposed by Manheim and Lane-Bostwick (1988):

$$
\text { Growth rate }\left(\mathrm{mm} \mathrm{Myr}^{-1}\right)=0.68 / \mathrm{Co}_{\mathrm{w}} 1.67
$$

Where, $\mathrm{Co}_{\mathrm{w}}$ is the Co concentration in wt $\%$ less detrital background concentration of $0.0012 \mathrm{wt} \%$.

One limitation of this method is that the equation does not take into account the possible hiatuses along the accretion process. Therefore, the calculated rates represent maximum values and the derived ages minimum values (Hein et al., 1990). The average growth rate obtained using the above equation for the studied nodules is $2,500 \mathrm{~mm}$
$\mathrm{Myr}^{-1}$ with low and high values ranging between 1,400 and 5,000 mm $\mathrm{Myr}^{-1}$. Hence, assuming that growth and accretion rate are constant, the minimum age of the nodules varies between 5,000 to 30,000 years, depending on the maximum diameter of the oxide layers.

\section{Discussion}

In this section, we first compare the results from the studies nodules with other deep-seabed polymetallic nodules and shallow-water and continental margin nodules from other ocean basins and tectonic settings of the world. Secondly, we deal with their specific relationship with hydrocarbon seeps and biomineralization products such as hydrocarbon-derived carbonate chimneys and crusts, and especially with the microbial-mediated activity. Finally, based on the growth rates, mineralogical, textural, and geochemical features, we discuss a genetic model of nodule growth that incorporates both diagenetic and hydrogenous processes.

\section{Comparison with polymetallic deep sea and shallow water nodules}

The nodules collected in the Gulf of Cadiz show a wide range of size, with a predominantly tabular morphology. These tabular or discoidal shapes have been mostly described from shallow-water 
nodules such as those reported from the Kara and Baltic seas (Bogdanov et al., 1995; Glasby et al., 1997). The cylindrical nodules are similar to tubular concretions formed around burrows reported in the Black Sea (Baturin et al., 2002). Physical characteristics such as maximum diameter, density, weight, and porosity are similar to nodules reported from the Pacific and East Indian Ocean basins (e.g., Raab and Meylan, 1977; Von Stackelberg, 1997; Palma and Pessanha, 2000) and from shallow-waters and continental margin in the Baltic Sea, Gulf of Finland, northern Russian seas and the Black Sea (e.g., Calvert and Price, 1977; Hlawatsch et al., 2002).

Compared to the composition of deep-sea nodules (Baturin, 1988), the studied nodules have high $\mathrm{Fe} / \mathrm{Mn}$ ratios $>1$, low trace metals, and are enriched in $\mathrm{Ca}, \mathrm{Mg}, \mathrm{Fe}$, Corg and $\mathrm{As}$, which is quite similar to nodular reported from the Black Sea (Baturin et al., 2002). Numerous authors have classified the oceanic nodules based on the ternary diagram $\mathrm{Mn}-\mathrm{Fe}-(\mathrm{Cu}+\mathrm{Ni}+\mathrm{Co}) \times 10$. According to this classification, nodules can be diagenetic characterized by $\mathrm{Mn} / \mathrm{Fe}>2.5$ rich in $\mathrm{Cu}$ and $\mathrm{Ni}$, and poor in $\mathrm{Co}$; hydrogenetic in which $\mathrm{Mn} / \mathrm{Fe} \approx 1$ and relatively high (high $\mathrm{Cu}+\mathrm{Ni}+\mathrm{Co}$ ); and hydrothermal where $\mathrm{Mn} / \mathrm{Fe}$ is either very high or very low with low $\mathrm{Cu}+\mathrm{Ni}+\mathrm{Co}$ (Bonatti et al., 1972; Lyle, 1981; Dymond et al., 1984; Fitzgerald and Gillis, 2006). The nodules studied here have $\mathrm{Mn} / \mathrm{Fe}<0.25$ and low contents of $\mathrm{Co}$, $\mathrm{Ni}, \mathrm{Cu}$ and REEs in all samples. There are abundant references about nodules from shallow waters and continental margins where $\mathrm{Fe}, \mathrm{Mn}$, and trace metals contents are rather similar to the nodules from the Gulf of Cadiz (Calvert and Price, 1977; Boström et al., 1982; Ingri, 1985; Glasby et al., 1997; Baturin et al., 2002). All of them display very low $\mathrm{Mn} / \mathrm{Fe}$ ratios as a result of growth by combined diagenetichydrogenous processes. In addition, the contents in some elements in the nodules from the Gulf of Cadiz (V, As, Ca, Mg, Ni, Co and Mo) are of similar to shallow-water nodules from the Baltic or Black seas (e.g., Volkov, 1979) than to deep-sea nodules. The average growth rate of the studied nodules $\left(2,500 \mathrm{~mm} \mathrm{Myr}^{-1}\right)$ is slower then those calculated for the Baltic Sea nodules with average rates of 20,000 mm $\mathrm{Myr}^{-1}$ (Zhamoida et al., 1996; Hlawatsch et al., 2002), but several orders of magnitude higher than that frequently found in hydrogenous deep-sea crusts (1-6 $\mathrm{mm} \mathrm{Myr}^{-1}$ ) (Hein, 2001) and nodules (several tons of $\mathrm{mm} \mathrm{Myr}^{-1}$ ). Therefore, fast growth rates emphasize the importance of sediment diagenetic processes (Reyss et al., 1982) and a shallow water environment. Furthermore, this relatively rapid accretion is probably one of the main causes for the overall low contents of transition metals in these continental margin nodules.

\section{Relationships with hydrocarbon seeps, methane- derived precipitates and bacterial activity}

The most distinctive characteristic of the studied nodules compared with other $\mathrm{Fe}-\mathrm{Mn}$ nodules fields is their association with hydrocarbon-derived carbonate chimneys and crusts. Beside this physical proximity, several other line of evidence support the close relationship between the nodules and hydrocarbons seeps. The organic carbon contained in the studied samples (av. 1.12\%) is substantially higher than in deep-sea polymetallic nodules (av. $0.1 \%$; Baturin, 1986) but quite similar to ferromanganese concretions from the Black Sea (av. 0.7\%; Baturin et al., 2002). Furthermore, the oxide layers of the studied nodules contain mature hydrocarbons derived from bacterial activity, with the presence of aromatic hydrocarbons characteristic of mature petroleum. These hydrocarbons also have been found within the methane-derived carbonate chimneys and crusts from the area. In addition, mature hydrocarbon gases $($ Ro $<1.2 \%)$ derived from kerogen type II and a mixture of kerogens of types II and III have been reported from sediments in the Moroccan mud volcano province of the Gulf of Cádiz (Stadnitskaia et al., 2006). Carbonate formation induced by anaerobic oxidation of methane (AOM) is confined in oxidising seawater, to anoxic sediment layers that are later exposed by erosional processes (e.g. Jørgensen, 1989; Stakes et al., 1999; Peckmann et al., 2001). Therefore, the present position of the carbonate chimneys and crusts on the seafloor suggests their exhumation by bottom current activity of Mediterranean outflow waters.

Micro-biological synthesis of oxides, carbonates, and sulphides in nodules and sediments has been reported by numerous authors (e.g., Hein and Koski, 1987; Nealson and Myers, 1992; Kohn et al., 1998; Stein et al., 2001). Micro-organisms such as archaea, sulphatereducing bacteria (SRB) and sulphide-oxidising bacteria (SOB) have been found in sediments and carbonates from mud volcanoes and mud-carbonate ridges in the Gulf of Cadiz (e.g., Niemann et al., 2006). These organisms use the hydrocarbon-enriched fluids from seeps in metabolic activity, giving rise directly or indirectly to minerals: carbonates and sulphides in anoxic environment (by archaea and SRB respectively) and oxides in oxidising environment (by SOB). Pyrites from the nodules exhibit textural (clots and framboids), geochemical (abundance of $\mathrm{C}_{\text {org }}$ ) and isotopic $\left(\delta^{34} \mathrm{~S}_{\mathrm{CDT}}\right.$ between +13 and $-41 \%$ ) characteristic typical of microbial-mediated pyrite, formed by anoxic oxidation of methane through a syntrophic interaction between methanotropic archaea and SRB (Hinrichs and Boetius, 2002). In this sense, filamentous and bulbous textures observed in Fe-Mn oxides in the nodules could have been generated by sulphide-oxidising bacteria within the upper oxidising sediment. Moreover, the existence of low molecular saturated fatty acids $\left(\mathrm{C}_{14^{-}}\right.$ $\mathrm{C}_{18}$ ), which usually sharply decreases during burial, indicate recent bacterial participation in organic matter degretation, probably linked with bacterial mineralization processes. Fatty acids present as bacterial markers in Fe-Mn nodules from the Pacific and Indian oceans, are related with the genetic types and element distribution in those deposits (Aleksandrova and Poluyaktov, 1996).

\section{Proposed genetic model for nodule growth}

Mineralogical, textural, and geochemical evidences are discussed here, which indicate that these nodules grew on and beneath seabed sediments by successive diagenetic and hydrogenous processes as a consequence of alternating episodes of burial and exhumation. The presence of detrital layers with burrows incorporated within the nodules by cementation by oxides indicates that they formed beneath the sediment-water interface and were later exposed by erosion, as occurs with carbonate chimneys and crusts. Exposure was likely caused by the MOW undercurrent, which in this area is characterised by current velocities of $20-30 \mathrm{~cm} / \mathrm{s}$ (Hernández Molina et al., 2006).

As reported for other shallow-water concretions (e.g., Loch Fyne, Scotland; British Columbia; Baltic Sea), the nodules recovered from the Gulf of Cadiz are found lying over brown oxidised sediments, whereas the subsurface sediments below a few millimetres to centimetres consist of olive-grey reduced muds containing $\mathrm{H}_{2} \mathrm{~S}$ and sulphides (Somoza et al., 2003). Textural equilibrium between rhombic oxide crystals and pyrite framboids (partial or totally pseudomorphed by goethite) point out that both crystalline structures are coeval. However, redox conditions necessary for pyrite and oxides formation are radically different. Presently in this area, carbonates and pyrites both form at depths of 20-200 $\mathrm{cm}$ below sea floor, within the sulphate-methane transition zone (SMT), under anaerobic conditions as a consequence of microbial-mediated methane oxidation and sulphate reduction (Niemann et al., 2006). Our observations suggest that crystals of goethite-Mn oxides are derived from replacement of hydrocarbon-derived carbonates (ankerite-dolomite, siderite, Mn-carbonates?). In this way, the rhombic oxide crystals under oxidising conditions as represent pseudomorphs of carbonate micritic crystals. Similar textures and associations of pyrite-carbonates have been observed both in mud breccia, high-sulphide sediments ejected by fluid venting (Martín Puertas et al., 2006), and in hydrocarbon-derived carbonate chimneys from the Gulf of Cadiz (e.g., Díaz-del-Río et al., 2003; González et al., 2006). In addition, goethite replacement of carbonates have been observed in buried corals from mud diapiric ridges in the Gulf of Cadiz (Kozlova et al., 2007). As a result of the strong erosive action of the undercurrents, iron-sulphides formed within a highly reduced zone only a few centimetres below seafloor, may come in contact with 
suboxic to oxic interstitial water from oxidizing bottom waters. The exhumation process drives to oxidation of $\mathrm{Fe}^{2+}$ to $\mathrm{Fe}^{3+}$ and, thus, to form Fe-oxyhydroxides.

The strong Fe enrichment in the studied nodules compared with deep sea nodules may be explained as a several sources of iron, oxidation of consequence of pyrites, detrital sources of iron, and diagenetic iron. On the other hand, nodules studied are depleted in Mn in the outer layers affected by the alteration front, probably formed after the exhumation. This fact is explained by the high geochemical mobility of $\mathrm{Mn}$ as a response to changes in the environment conditions. Thus, the chemistry of the MOW in the area, which is characterised by relatively low values of dissolved oxygen in the water (160-170 $\mu \mathrm{mol} / \mathrm{kg}$ ) (Cabeçadas et al., 2002) could have contributed together with the intense undercurrent to the depletion of manganese from the outer layers in the exhumed nodules. In contrast, these outer layers are iron-rich indicating a recent period of stagnation in the nodule growth. The high porosity observed in these outer layers reflects dissolution related to changes in the geochemistry of the environment. Zero to small negative Ce anomaly in the studied nodules suggests that they were formed at a lower redox level in the vicinity of the redox boundary, and in agreement with diagenetic growth and later exhumation. The presence of a second generation of sulphides and kutnahorite precipitates that filled pores and cracks of nodules imply the existence of reduced or suboxic micro-niches in an oxic environment. Reducing micro-niches with sulphide precipitates have been observed in Fe-Mn nodules (e.g., Baturin, 1986)

Therefore, Mn-rich and $\mathrm{Mn}-\mathrm{Fe}$ mixed layers may represent active growth beneath the sediment-water interface in the vicinity of the redox boundary where $\mathrm{Mn}$ and $\mathrm{Fe}$ are directly supplied from sediment pore waters. Fe-rich layers with very low growth rates are related to periods of exposure to bottom waters iron oxides were precipitated from the sea-water and $\mathrm{Mn}$ was dispersed by bottom currents. Hence, if the nodules lie uncovered on the sea-floor they grow predominantly hydrogenetically whereas when they are covered by sediment then they grow predominantly diagenetically.

\section{Summary}

Here we report the discovery and sampling of Fe-Mn nodules along the continental margin of the Gulf of Cadiz. The nodule fields extend along the mid-continental slope at an average depth of $900 \mathrm{~m}$ on continental crust in contrast to deep sea nodules, which form on abyssal plain sediments above oceanic crust (Cronan, 1977). The most striking characteric of the nodule field reported here is that the area supports a high abundance of mud volcanoes, diapirs, pockmarks, and carbonate chimneys, reflecting a great release of deep-seated hydrocarbons to the sea floor through faults and sediment pores (e.g., Somoza et al., 2002; León et al., 2007). Nodules were found together with large amounts of hydrocarbon-derived chimneys and crusts and mud breccia deposits at the base of a sequence of carbonate-mud mounds named the Guadalquivir Diapiric Ridge that act as a barrier for the Mediterranean outflow bottom current (Díaz-del-Río et al., 2003).

The nodules are predominatly tabular-irregular in morphology and grow concentrically around a nucleus of Miocene blue marls ejected by fluid venting from the underlying units of the so-called "Olistostrome Mass" (Maldonado et al., 1999). Internally, nodules are composed of layers, clearly concentric in small nodules, but forming complex morphologies in large and composite nodules. All nodules studied show similar petrographic characteristics being mainly formed by Fe-Mn oxyhydroxides. These oxides display characteristic rhombic shapes with a relatively large size of crystals compared to cryptocrystalline Fe-Mn oxides from other shallow as well as deep ocean nodules. Quartz and phyllosilicates (detrital) are commonly present although in much smaller proportion than the Fe-Mn oxyhydroxides. The textures developed by the $\mathrm{Fe}$ and Mn oxyhydroxides are dendritic, massive, laminated and mottled. Nodules show a similar geochemistry with shallow water nodules rather than deep-sea polymetallic nodules. They have a high mean abundance of $\mathrm{Fe}(39.03 \%)$, moderate $\mathrm{Mn}(5.84 \%)$, and low contents of trace metals and REEs. Based on the cobalt chronometer method, an average of 2,500 mm Myr ${ }^{-1}$ was calculated for nodule growth, being several orders of magnitudes faster than growth rates of deep sea polymetallic nodules.

We propose that genesis both diagenetic and hydrogenous processes were involved in nodule growth; beneath and on the seabed sediment, as a consequence of alternating episodes of burial and exhumation due to bottom current activity of Mediterranean outflow waters. The presence of mature hydrocarbons within the nodules indicates that diagenetic processes are related to deep-seated hydrocarbon seeps, probably through microbial-mediated anaerobic oxidation of hydrocarbons. Variability in hydrogenous nodule growth may be related to changes in the interface between the oxygenated North Atlantic deep waters and the Mediterranean outflow waters.

These considerations suggest that the formation of these Fe-Mn nodule fields must be reviewed in the context of fluid venting in the Gulf of Cadiz to form complex deep-water chemosynthetic systems composed of distinct types of mineralization process, products, and mineral ores.

\section{Acknowledgements}

This work has been funded thanks to a research fellowship of the Geological Survey of Spain within the framework of the European Science Foundation EuroCORE-EuroMARGINS projects: "MOUNDFORCE" (O1-LEC-EMA06F, REN-2002-11668-EMAR) and "MVSEIS" (O1-LEC-EMA24F, REN-2002-11669-EMAR). The authors thank all the scientific and technical personnel who participated in the oceanographic cruises of the "TASYO" project, of the R/V "Cornide de Saavedra" and R/V "Hespérides", for the data acquisition and their expertise in collecting the samples, essential for the elaboration of this paper. We also thank personnel of the "Centro de Microscopía Electrónica Luis Bru", "Universidad Complutense de Madrid" (UCM), "Centro de Astrobiología" (CSIC/INTA), "Laboratorio de Estratigrafía Biomolecular" (UPM), and to the laboratories of the "Instituto Geológico y Minero de España" (IGME), the facilities given for the use of its equipments. The detailed review comments of Dr. James R. Hein greatly improved the manuscript. Brian George is gratefully acknowledged for help with the English version of the paper.

\section{References}

Aleksandrova, O.A. and Poluyaktov, V.F., 1996, Fatty acid composition of the iron-manganese nodules and surrounding sediments in the Pacific and Indian oceans. Oceanology, v. 35, n. 5, 630-637.

Auzende, J.M., Olivet, J.L., and Pastouret, L., 1981, Implication structurales et paléogeographiques de la presence de Messinien a l'ouest de Gibraltar. Marine Geology, 43, 9-18.

Baraza, J. and Ercilla, G., 1996, Gas-charged sediments and large pockmark like features on the Gulf of Cadiz slope (SW Spain). Marine and Petroleum Geology, v. 13, n. 2, 253-261.

Baturin, G.N., 1986, Geochemistry of oceanic ferromanganese nodules. Moscow: Nauka.

Baturin, G.N., 1988, The geochemistry of manganese and manganese nodules in the ocean. In: D. Riedel Publ. Co. 342 pp.

Baturin, G.N., Gorshkov, A.I., Magazina, L.O. and Bogdanova, O.Yu., 2002, Structure and composition of ferromanganese-phosphate nodules from the Black Sea. Lithology and Mineral Resources, v. 37, n. 4, 374-385.

Bogdanov, Yu.A., Gurvich, E.G., Bogdanova, O.Yu., Ivanov, G.V., Isaeva, A.B., Murav'ev, K.G., Gorshkov, A.I. and Dubinina, G.I., 1995, Ferromanganese nodules of the Kara Sea. Oceanology, v. 34, n. 5, 722-732.

Bonatti, E.; Kraemer, T. and Rydell, H., 1972, Classification and genesis of submarine iron-manganese deposits. In: Horn, D.R. (Ed.). Ferromanganese deposits of the ocean floor. Arden House. New York, 149-165.

Bonnin, J.,Olivet, J.L., and Auzende, J.M., 1975, Structure en nappe a 1'ouest de Gibraltar. C.R. Academy of Science, 280 (5), 559-562. 
Borges, J.F., Fitas A.J.S., Bezzeghoud M. and Teves-Costa, P., 2001, Seismotec tonics of Portugal and its adjacent Atlantic area. Tectonophysics, 337, 373-387.

Boström, K., Wiborg, L. and Ingri, J., 1982, Geochemistry and origin of ferromanganese concretions in the Gulf of Bothnia. Marine Geology, 50, 1- 24.

Cabeçadas, G., Brogueira, M.J. and Gonçalves, C., 2002, The chemistry of Mediterranean outflow and its interactions with surrounding waters. DeepSea Research II, 49, 4263-4270.

Calvert, S.E. and Price, N.B., 1977, Shallow water, continental margin and lacustrine nodules: distribution and geochemistry. In: Glasby, G.P., (Ed.) Marine manganese deposits. Elsevier Oceanography Series, Amsterdam, 45-86.

Cavazza, W., Roure, M. R., Spakman, W., Stampli, G. M. and Zigler, P. A., 2004 The trasmed Atlas: the Mediterranean region from crust to mantle. SpringerVerlag Berlin Heidelberg, Germany, 141 pp.

Cronan, D.S., 1977, Deep-sea nodules: distribution and geochemistry In: Glasby, G.P.,(Ed.) Marine manganese deposits. Elsevier Oceanography Series, Amsterdam, $11 \mathrm{v} 44$

Dekov, V.M. and Savelli, C., 2004, Hydrothermal activity in the SE Tyrrhenian Sea: an overview of 30 years of research. Marine Geology, 204, 161-185.

Dewey, J.F., Helman, M.L., Turco, E., Hutton, D.H.W. and Knott, S.D., 1989, Kinematics of the Western Mediterranean: Alpine Tectonics (ed. Coward, M.). Special Publication Geological Society of London, London, 45, $265-283$

Díaz-del-Río, V., Somoza, L., Martínez-Frias, J., Hernández-Molina, F.J., Lunar, R., Fernández-Puga, M.C., Maestro, A., Terrinha, P., Llave, E., García, A., García, A.C., Vázquez, J.T., 2001, Carbonate chimneys in the Gulf of Cadiz: Initial report of their petrography and geochemistry. Final Proc. Int. Conf. Geological Processes on Deep-Water European Margins, Moscow, Russia. UNESCO IOC Workshop Report 175, 53-54.

Díaz-del-Río, V., Somoza, L., Matínez Frías, J., Mata, M.P., Delgado, A. Hernández Molina, F.J., Lunar, R., Martín Rubí, J.A., Maestro, A., Fernádez Puga, M.C., León, R., Llave, E., Medialdea, T. and Vazquez, J.T., 2003, Vast field of hydrocarbon-derived carbonate chimneys related to the accretionary wedge/olistostrome of the Gulf of Cadiz. Marine Geology, 195, 177-200.

Dymond, J., Lyle, M., Finney, B., Piper, D.Z., Murphy, K., Conard, R. and Pisias, N., 1984, Ferromanganese nodules from MANOP Sites H, S and R- control of mineralogical and chemical composition by multiple accretionary processes. Geochim. Cosmochim. Acta, 48, 931-950.

Evans, A.M., 1980, An introduction to ore geology. Blackwell Scientific Publication, Oxford. $356 \mathrm{pp}$.

Fernández Puga, M.C., 2004, Diapirismo y estructuras de expulsión de gases hidrocarburos en el talud continental del Golfo de Cádiz. Tesis Doctoral. Universidad de Cadiz. 335 pp

Fitzgerald, C.E. and Gillis, K.M., 2006, Hydrothermal manganese oxide deposits from Baby Bare seamount in the Northeast Pacific Ocean. Marine Geology, $225,145-156$.

Gardner, J.M., 2001, Mud volcanoes revealed and sampled on the Moroccan continental margin. Geophysical Research Letters, 28 (2), 339-342.

Glasby, G.P., (Ed.), 1977, Marine manganese deposits. Elsevier Oceanography Series, 15. Amsterdan. 523 pp

Glasby, G.P., Emelyanov, E.M., Zhamoida, V.A., Baturin, G.N., Leipe, T., Bahlo, R. and Bonacker, P., 1997, Environments of formation of ferromanganese concretions in the Baltic Sea: a critical review. In: Nicholson, K Hein, J.R., Bühn, B. and Dasgupta, S. (Eds) Manganese Mineralization: Geochemistry and Mineralogy of Terrestrial and Marine Deposits. Special Publication Geological Society of London, London, 119: 213-237.

González, F.J., 2004, Los nódulos de hierro-manganeso del Golfo de Cádiz. Trabajo de Suficiencia Investigadora. Facultad de Ciencias Geológicas. Universidad Complutense de Madrid. 76 pp.

González, F.J., Pinheiro, L.M., Magalhães, V.H., Ivanov, M., Somoza, L. and Merinero, R., 2006, Sulphate-reducing bacteria as a nucleation sites for pyrite in carbonate chimneys from the Vernadsky Ridge, Moroccan margin of the Gulf of Cadiz. Final Proc. Int. Conf. Geological processes on Deep-Water European Margins, Moscow, Russia. UNESCO IOC Workshop Report (in press).

Gutscher, M.-A., Malod, J., Rehault, J.-P., Contrucci, I., Klingelhoefer, F., Mendes-Victor, L. and Spakman, W., 2002, Evidence for active subduction beneath Gibraltar. Geology, 30, 1071-1074.

Hein, J.R. and Koski, R.A., 1987, Bacterially mediated diagenetic origin for chert-hosted manganese deposits in the Franciscan Complex, California Coast Ranges. Geology, v. 15, $\mathrm{n}^{\circ} 8,722-726$.

Hein, J.R., Schulz, M.S. and Kang, J.K., 1990, Insular and submarine ferromanganese mineralization of the Tonga-Lau region. Marine Minerals, 9, 305-354

Hein, J.R., 2001, Cobalt-rich ferromanganese crusts: global distribution, composition, origin and research activities. In: ISA (Ed) Minerals other than polymetallic nodules of the International Seabed Area. Workshop Report, Kingston, Jamaica: 188-272.

Hernández Molina, F.J., Llave, E., Somoza, L., Fernández Puga, M.C. Maestro, A.;León, R., Medialdea, T., Barnolas, A., García, M., Díaz-del-Río, V., Fernández Salas, L.M., Vázquez, J.T., Lobo, F.J., Alveirinho Díaz, J.A., Rodero, J. and Gardner, J., 2003, Looking for clues to paleoceanographic imprints: A diagnostic of the Gulf of Cadiz contourite depositional system. Geology, 31 (1), 19-22.

Hernández Molina, F.J., Llave, E., Stow, D.A.V., Garcia, M., Somoza, L., Vázquez, J.T., Lobo, F.J., Maestro, A., Díaz-del-Río, V., León, R., Medialdea, T., and Gardner, J., 2006, The contourite depositional system of the Gulf of Cadiz: A sedimentary model related to the bottom current activity of the Mediterranean outflow water and its interaction with the continental margin. Deep-Sea Research II, 53, 1420-1463.

Hinrichs, K.-U. and Boetius, A., 2002, The anaerobic oxidation of methane: new insights in microbial ecology and biogeochemistry. In: Wefer, G., Billett, D. Hebbeln, D., Jørgensen, B.B., Schlüter, M., van Weering, T.C.E. (Eds.), Ocean Margin Systems. Springer-Verlag, Berlin, 457- 477.

Hlawatsch, S., Neumann, T., van den Berg, C.M.G., Kersten, M., Harff, J. and Suess E., 2002, Fast-growing, shallow-water ferro-manganese nodules from the western Baltic Sea: origin and modes of trace element incorporation. Marine Geology, 182, 373-387.

Ingri, J., 1985, Geochemistry of ferromanganese concretions and associated sediments in the Gulf of Bothnia. PhD thesis, University of Lulea

ISA, International Seabed Authority, 1999, Deep-seabed polymetallic nodule exploration: development of environmental guidelines, Proceedings of International Seabed Authority's workshop held in Sanya, Hainand Island, People's Republic of China, 1-5 June 1998, 289 pp.

ISA, International Seabed Authority, 2000, Regulation on prospecting and exploration for polymetallic nodules in the area (ISBA/6/A/18), In Selected decisions and documents of the Sixth Session, 31-68.

Ivanov, M.K., Kenyon, N., Nielsen, T.,Wheeler, A., Monteiro, J.,Gardner, J., Comas, M., Akhmanov, G., Akhmetzhanov, A., and Scientific Party of the TTR-9 cruise, 2000, Goals and principle results of the TTR-9 cruise. Final Proc. Int. Conf. Geological processes on European Continental Margins, Granada, Spain. UNESCO IOC Workshop Report 168, 24-25.

Jørgensen, N.O., 1989, Holocene methane-derived, dolomite-cemented sandstone pillars from the Kattergat, Denmark. Marine Geology, 88, 71-81.

Kohn, M.J., Riciputi, L.R., Stakes, D., and Orange, D.L., 1998, Sulphur isotope variability in biogenic pyrite: reflections of heterogeneous bacterial colonisation? American Mineralogists, 83, 1454-1468.

Kozlova, E., Ivanov, M. and Blinova, V., 2007, The replacement of aragonite by authigenic carbonates (in the mud diapiric ridges, the Gulf of Cadiz) Geophysical Research Abstracts, v. 9, 06912.

León, R., Somoza, L., Ivanov, M.K., Díaz-del-Río, V., Lobato, A., HernándezMolina, F.J., Fernández-Puga, M.C., Maestro, A., Medialdea, T., Alveirinho, J., Días, J.A. and Vázquez, J.T., 2001, Seabed morphology and gas venting in the Gulf of Cadiz mud volcano area: Imagery of multibeam data and ultrahigh resolution data. Final Proc. Int. Conf. Geological Processes on DeepWater European Margins, Moscow, Russia. UNESCO IOC Workshop Report 175, 43-45.

León, R., Somoza, L., Medialdea, T., Maestro, A., Díaz del Río, V. and Fernández Puga, M.C., 2006, Classification of deep sea-floor features associated with methane seeps along the Gulf of Cadiz continental margin. Deep Sea research II, 53, 1464-1481.

León, R., Somoza, L., Medialdea, T., González, F.J., Díaz-del-Río, V., Fernández-Puga, M.C., Maestro, A. and Mata, M.P., 2007, Sea-floor features related to hydrocarbon seeps in deepwater carbonate-mud mounds of the Gulf of Cadiz: from mud flows to carbonate precipitates. Geo-Marine Letters v. 27, 237-247.

Lonergan, L. and White, N., 1997, Origin of the Betic-Rif mountain belt. Tectonics, v. 16, 504-522.

Lyle, M., 1981, Formation and growth of ferromanganese oxides on the Nazca plate. In: Kulm, L.D., Dymond, J., Dasch, E.J. and Hussong, D.M. (Eds.) Nazca Plate: crustal formation and Andean convergence. Geol. Soc. Am. Mem., 154, 269-293.

Maestro, A., Somoza, L., Medialdea, T., Talbot, C. J., Lowrie, A., Vázquez, J. T., and Díaz-del-Río, V., 2003, Large scale slope failure involving Triassic and Middle Miocene salt and shale in the Gulf of Cadiz (Atlantic Iberian Margin) Terra Nova, 15, 380-391.

Magalhães, V.H., Pinheiro, L.M. and Ivanov, M., 2005, Methane-derived authigenic carbonates in the Gulf of Cadiz: cartography, distribution and controls. Eos Trans. AGU, 86 (52), Fall Meet. Suppl., Abstract OS33C-1484.

Maldonado, A., Somoza, L. and Pallarés, L., 1999, The Betic Orogen and the Iberian-african boundary in the Gulf of Cadiz: geological evolution (central North Atlantic). Marine Geology, 155, 9-43.

Manheim, F.T. and Lane-Bostwick, C.M., 1988, Cobalt in ferromanganese crusts as a monitor of hydrothermal discharge on the Pacific sea floor. Nature, 335, $59-62$.

Martín-Puertas C., Fernández-Puga M.C., Mata M.P., Vázquez Garrido J.T., Díaz-del-Río V. and Somoza L., 2006, Naturaleza de la brecha fangosa de volcanes de fango del Golfo de Cádiz: sistema diapírico del Guadalquivir y zona Tasyo. Revista de la Sociedad Geológica de España, 19 (3-4).

Medialdea, T., Vegas, R., Somoza, L., Vázquez, J.T.; Maldonado, A., Díaz-delRío, V., Maestro, A., Córdoba, D. and Fernández Puga, M.C., 2004, Structure and evolution of the "Olistostrome" complex of the Gibraltar Arc in the Gulf of Cadiz (eastern Central Atlantic): evidence from two long seismic cross-sections. Marine Geology, 209 (1-4), 173-198. 
Murray, J. and Renard, A.F., 1891, Deep-sea deposits. Reports of the Scientific Results Explor. Voyage Challenger. 525 pp.

Nealson, K.H. and Myers, C.R., 1992, Microbial reduction of manganese and iron: new approaches to carbon cycling. Applied and Environmental Microbiology, 58-2, 439-443.

Nicholson, K., Hein, J.R., Bühn, B. and Dasgupta, S., (Eds.), 1997, Manganese Mineralization: Geochemistry and Mineralogy of Terrestrial and Marine Deposits. Special Publication Geological Society of London, London, 119 $370 \mathrm{pp}$.

Niemann, H., Duarte, J., Hensen, C., Omoregie, E., Magalhaes, V.H., Elvert, M. Pinheiro, L.M., Kopf, A. and Boetius, A., 2006, Microbial methane turnover at mud volcanoes of the Gulf of Cadiz. Geochimica et Cosmochimica Acta, v.30, 5336-5355.

Palma, J.J.C. and Pessanha, I.B.M., 2000, Depósitos ferromanganesíferos de océano profundo. Brazilian Journal of Geophysics, v. 18 (3), 431-446.

Peckmann, J., Reimer, A., Luth, U., Luth, C., Hansen, B.T., Heinicke, C., Hoefs, J. and Reitner, J., 2001, Methane-derived carbonates and authigenic pyrite from the northwestern Black Sea. Marine Geology, 177, 129-150.

Pinheiro, L.M., Ivanov, M.K., Sautkin, A., Akhmanov, G., Magalhaes, V.H., Volkonskaya, A., Monteiro, J.H., Somoza, L., Gardner, J., Hamouni, N. an Cunha, M.R., 2003, Mud volcanism in the Gulf of Cadiz: results from the TTR-10 cruise. Marine Geology, 195, 131-151.

Raab, W.J. and Meylan, M.A., 1977, Morphology. In: Glasby, G.P., (Ed.) Marine manganese deposits. Elsevier Oceanography Series, Amsterdam, 109-146.

Reyss, J. L., Marchig, V. and Ku, T. L., 1982, Rapid growth of a deep-sea manganese nodule. Nature, v. 295, 5848, 401-403

Riaza, C. and Martinez del Olmo, W., 1996, Depositional model of the Guadalquivir-Gulf of Cadiz Tertiary basin, in: Friend, P.F. and Dabrio, C.J., ed. Tertiary basin of Spain: the stratigraphic record of crustal kinematics. Cambridge University Press, 330-338.

Rona, P., 2002, Marine minerals for the 21st century. Episodes, 25, 2-12.

Rona, P., 2003, Resources of the sea floor. Science, 299, 673-674.

Royden, L.H., 1993, The tectonic expression of slab pull at continental convergent boundaries. Tectonics, 12, 303-325.

Somoza, L., Gardner, J.M., Díaz-del-Río, V., Vázquez, J.T., Pinheiro, L., Hernández-Molina, F.J. and TASYO scientific parties, 2002, Numerous Methane Gas-related sea floor structures identified in Gulf of Cadiz. EOS Transactions, v. 83 (47), 541-543. American Geophysical Union.

Somoza, L., Díaz-del-Río, V., León, R., Ivanov, M., Fernández-Puga, M.C. Gardner, J.M., Hernández-Molina, F.J., Pinheiro, L.M., Rodero, J., Lobato, A., Maestro, A., Vázquez, J.T., Medialdea, T. and Fernández-Salas L.M., 2003, Seabed morphology and hydrocarbon seepage in the Gulf of Cadiz mud volcano area: Acoustic imagery, multibeam and ultra-high resolution seismic data. Marine Geology, 195, 153-176.
Stakes, D.S., Orange, D., Paduan, J.B., Salamy, K.A. and Maher, N., 1999, Coldseeps and authigenic carbonate formation in Monterey Bay. California. Marine Geology, 159, 93-109.

Stadnitskaia A., Ivanov M.K., Blinova V., Kreulen R. and van Weering T.C.E., 2006, Molecular and carbon isotopic variability of hydrocarbon gases from mud volcanoes in the Gulf of Cadiz, NE Atlantic. Marine and Petroleum Geology, 23, 281-296.

Stein, L.Y., La Duc, M.T., Grundl, T.J. and Nealson, K.H., 2001, Bacterial and archaeal populations associated with freshwater ferromanganese micronodules and sediments. Environmental Microbiology, 3 (1), 10-18.

Torrelli, L., Sartori, R., and Zitellini, N., 1997, The giant chaotic body in the Atlantic Ocean of Gibraltar: new results from a deep seismic reflection survey. Marine and Petroleum Geology, 14 (2), 125-138.

Verlaan, P.A., Cronan, D.S. and Morgan, C.L., 2005, A comparative analysis of compositional variations in and between marine ferromanganese nodules and crusts in the South Pacific and their environmental controls. Progress in Oceanography, 63, 125-158.

Volkov, I.I., 1979, Ferromanganese nodules. In Oceanologiya, Khimiya Okeana, v. 2, Geokhimiya Donnykh Osadkov, 414-467.

Von Stackelberg, U., 1997, Growth history of manganese nodules and crust of the Peru Basin. In: Nicholson, K., Hein, J.R., Bühn, B. and Dasgupta, S. (Eds) Manganese Mineralization: Geochemistry and Mineralogy of Terrestrial and Marine Deposits. Special Publication Geological Society of London, London, 119: 153-176.

Zhamoida, V.A., Butylin, V.P., Glasby, G.P. and Popova, I.A., 1996, The nature of ferromanganese concretions from the Eastern Gulf of Finland, Baltic Sea. Marine Georesources and Geotechnology, 14, 161-175.

F. Javier González graduated from the University of Salamanca in 1999 with a degree in Geology. He currently has a doctoral fellowship at the Spanish Geological Survey (IGME) and is Collaborator at the Department of Crystallography and Mineralogy of the "Universidad Complutense de Madrid" (UCM). His research activities are concerned with mineralogy, petrology, geochemistry and metallogenesis (mainly oceanic mineral deposits).

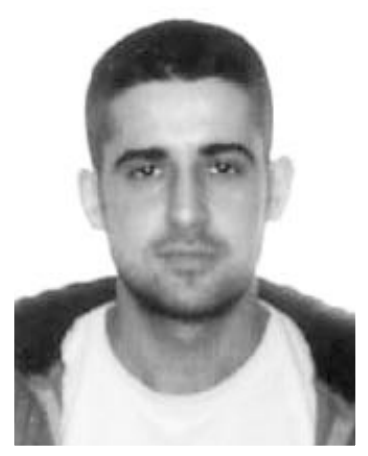

\title{
CALL FOR PAPERS
}

Episodes is the quarterly science and news journal of the International Union of Geological Sciences (IUGS). It focuses on the publication of results of scientific research and other information addressing issues of interest to the global earth-science community. Special emphasis is given to topics involving geological aspects of population growth and economic development and their resulting impacts on or implications for society. As the principal publication of the IUGS, Episodes also carries information about IUGS scientific programs and activities to the extent necessary to communicate effectively with the worldwide IUGS constituency.

Contributions of the following types of manuscripts are here solicited:

- review papers

- scientific articles

- conference reports

- news and views

- letters to editor

- book reviews

- information on training courses (especially those geared to participants from developing countries)

- noteworthy new publications, including national or regional geologic maps

Episodes also invites photos or other images for the front cover. Photos must be of high technical quality and tell an interesting geological story. A color transparency and one color print (at least $9 \mathrm{~cm} \times 12.6 \mathrm{~cm}$ ) are required for submission, which should be supplemented with a short explanatory paragraph (no more than 100 words).

Please address all contributions to:

\author{
The Editor \\ Episodes \\ P. O. Box 823, 26 Baiwanzhuang Road \\ 100037 Beijing, CHINA \\ Tel: +86-10-68320827, +86-10-68329084 \\ Fax: +86-10-68328928 \\ E-mail: episodes.journal@yahoo.com
}

